\title{
Study on Cosmeceutical Activities and Anti-inflammatory Activities of Magnolia biondii Extracts
}

Young-Hun Kim', Ji-Yeon Sung ${ }^{2}$, Kyo-Seong $\mathrm{SeO}^{3}$, Jae-Cheon $\mathrm{Shin}^{4}$, Byung-So $\mathrm{Kim}^{5}$, Jeong-Hyun Yeum ${ }^{6}$ and Jin-Tae Lee *

${ }^{1}$ Skin Science R\&D Center, MEDIWAY Korea Co., Ltd, Daegu 702-894, Korea

${ }^{2}$ Medicinal Nano Material Institute, Bio-FD\&C Co, Ltd, Jeonnam 519-801, Korea

${ }^{3}$ Small and Medium Business Administration, Daegu 704-833, Korea

${ }^{4}$ Pohang Center for Evaluation of Biomaterials, KyungBuk 790-834, Korea

${ }^{5}$ Division of Chemical Industry, Yeungnam College of Science \& Technology, Daegu 705-703, Korea

${ }^{6}$ Department of Bio-Fibers and Materials Science, Kyungpook NationalUniversity, Daegu 702-701, Korea

${ }^{7}$ Department of Cosmeceutical Science, Daegu Haany University, KyungBuk 712-715, Korea

Received January 19, 2012 /Revised April 16, 2012 /Accepted May 30, 2012

\begin{abstract}
Existing pharmaceutical studies show that Magnolia biondii is effective in treating rhinitis and in reducing cholesterol, given its endogenous, volatile ingredients. The study herein seeks to assess the cosmeceutical activities and anti-inflammatory activities of Magnolia biondii extracts for possible application as cosmetic ingredients. The cosmeceutical and anti-inflammatory activities were investigated using hydroxyl radical scavenging, superoxide dismutase (SOD)-like activity, xanthine oxidase (XO) inhibition, cell viability, nitric oxide (NO) inhibition, and inducible nitric oxide synthase (iNOS) expression by Western blotting. Magnolia biondii extracts were identified to have antioxidant activities in hydroxyl free radical scavenging, SOD-like activity, and XO inhibition. In testing the anti-inflammatory activities of the extracts, NO production was inhibited in a dose-dependent manner. Additionally, in a dose-dependent manner, the Magnolia biondii extracts were able to suppress iNOS expression in LPS-stimulated RAW 264.7 macrophage cells. From these results, Magnolia biondii showed adequate potential for application in cosmetic production and related industries as well as a functional material.
\end{abstract}

Key words : Anti-inflammatory, cosmeceutical, induced nitric oxide synthase, Magnolia biondii, nitric oxide

\section{서 론}

Hydrogen peroxide, Superoxide anions 와 Singlet oxygen 과 같은 활성산소종(ROS)에 의해 유도된 산화적 스트레스는 여러 가지 질병 및 정상세포의 노화를 일으킨다. 이와 같은 질병과 노화를 방지하기 위해서 사용되는 항산화제는 산화로 인해 여러 가지 바람직하지 않은 화합물의 형성을 방지하기 위해 지질 시스템 내에 첨가된다. 산화에 의해 생성되는 각종 산화 생성물은 DNA를 손상시키거나 암을 유발하며 인간의 노화와도 관계가 있는 것으로 알려져 있다[2,27]. 일반적으로 합성 항산화제로 널리 알려진 BHA (Butylated hydroxyl ani$\mathrm{sol}$ )와 BHT (Butylated hydroxyl toluene)는 그 효과와 경제성 그리고 안정성 때문에 많이 사용해 왔지만 합성 식품첨가물의 일반적인 기피 현상뿐만 아니라 과다 섭치시 간, 위장점막, 폐, 신장, 순환계 등에 심각한 독성 작용을 일으키는 것으로

*Corresponding author

Tel : +82-53-819-1430, Fax : +82-53-819-1430

E-mail : jtlee@dhu.ac.kr
알려져 안전한 대체 항산화제의 개발이 시급하다[3,6,13]. 또한, 이러한 산화 스트레스는 수많은 생리학적 병리학적 현상에서 중요한 역할을 하는데 산화 스트레스에 수반되는 활성 산소 종으로서 Singlet oxygen $\left({ }^{1} \mathrm{O}_{2}\right)$, Superoxide $\left(\mathrm{O}^{2-}\right)$, Hydroxyl radical $(\mathrm{HO})$, Hydrogen peroxide $\left(\mathrm{H}_{2} \mathrm{O}_{2}\right)$ 이 있으며, 이러한 활 성 산소 종들은 염증 반응에 관여한다. 염증반응은 생체나 조 직에 물리적 작용이나 화학적 물질, 세균감염 등의 어떠한 변 화가 가해질 때 그 손상부위를 재생하려는 기전이며, 일단 자 극이 가해지면 국소적으로 Histamine, Serotonine, Bradykinin, Prostaglandins, Hydroxyeicosatetraenoic acid (HETE), Leukotriene과 같은 혈관 활성물질이 유리되어 혈관 투과성이 증대되면서 염증을 유발시키고, 이러한 염증을 통해 피부의 손상과 노화 등을 촉진시킨다. 따라서 최근에 식물유 래 및 해양유래 천연소재 유효성분 개발과 연구가 활발이 진 행되고 있다[9,15,21].

신이화(辛夷花, Magnoliae Flos)는 오래 전부터 중국 한의학 에서 가장 많이 사용되는 한방소재 중의 하나이며 특히, 알레 르기 비염, 축농증, 감기, 충혈 완화제, 진통제등에 효과적으로 
사용되어 왔다. 신이화는 목련꽃 봉오리로써, 일반적으로 목 련은 붉은 색을 피우는 자목련과 흰색꽃을 피우는 백목련으로 나뉜다. 여름부터 다음해 봄까지 조금씩 계속 자라면서 꽃봉 오리는 껍질에 쌓인 채 벌어 지지 않고 사계절이 지나야 벌어 지는 데 신이화는 벌어지기 직전의 백목련의 꽃봉오리를 말한 다. 특히 백목련 꽃봉오리는 약간 매운맛을 지니고 있으며, 이 매운맛은 발산하는 효능을 지니고 있어 코 막힘이나 콧물 을 시원하게 딿어 주며 고지혈을 예방하는데 효과가 있고, 또 한 종양세포 분열증식[29]과 혈소판 응고완화[23], 천식 등에 효과가 있는 것으로 알려져 있다. 또한, 신이화 추출물은 알러 지와 염증을 일으키는 매개체인Histamine, Prostaglandin E2 $\left(\mathrm{PGE}_{2}\right)$, Platelet active factor $(\mathrm{PAF})$, Nitric oxide $(\mathrm{NO})$ 와 Interleukin-1a (IL-1a), Tumor necrosis factor-a (TNF-a)의 사 이토카인을 억제시킨다[18,25].

위와 같이 신이화추출물의 약리활성 검증을 통하여 제약분 야에서 많은 연구가 활발히 진행되었으나 화장품 관련 연구결 과는 아직 보고된 바 없어 본 연구팀에서는 신이화를 추출하 고, 화장품약리활성 및 항염증 실험을 진행하여 화장품 소재 로서의 사용 가능성을 확인하고자 한다.

\section{재료 및 방법}

\section{시료 제조}

본 실험에 사용된 신이화는 경북 영천시 소재의 동우당제약 (주에서 구입하여 사용하였다. 시료의 추출은 열수 추출물의 경우 시료에 증류수 10 배 양을 가하여 $85^{\circ} \mathrm{C}$ 에서 3시간 환류 냉각 추출하여 상등액과 침전물을 분리하여 3 회 반복 추출하 였으며, 에탄올 추출물의 경우 $70 \%$ 에탄올을 시료 중량의 10 배 양을 가하여 실온에서 24 시간 침지하여 상등액과 침전물을 분리하여 동일한 방법으로 3 회 반복 추출하였다. 각 추출물은 원심분리 및 여과, 농축(HS-10SP, Hanshin, Korea) 후 동결건 조(FD5525, Ilshin, Korea) 하여 냉장실에 보관하면서 본 실험 의 시료로 사용하였다(Fig. 1).

\section{화장품약리활성 측정}

\section{$\mathrm{DPPH}$ radical 소거능 측정}

DPPH radical 소거능 측정은 Blois [4] 의 방법을 변형하여 다음과 같이 측정하였다. 각 시료용액 $100 \mu 1$ 에 $0.2 \mathrm{mM}$ 의 1,1-diphenyl-2-picrylhydrazyl (DPPH) $50 \mu \mathrm{l}$ 넣고 교반한 후 30 분간 실온에서 반응시키고, ELISA reader기(Powervave XS2, Biotek, USA)를 이용하여 $517 \mathrm{~nm}$ 에서 흡광도를 측정하 였다.

Superoxide dismutase (SOD) 유사활성 측정

SOD 유사활성은 Marklund 등[19]의 방법을 변형하여 측정 하였다. 각 시료용액 $20 \mu \mathrm{l}$ 에 Tris- $\mathrm{HCl}$ 완충용액(50 mM Tris

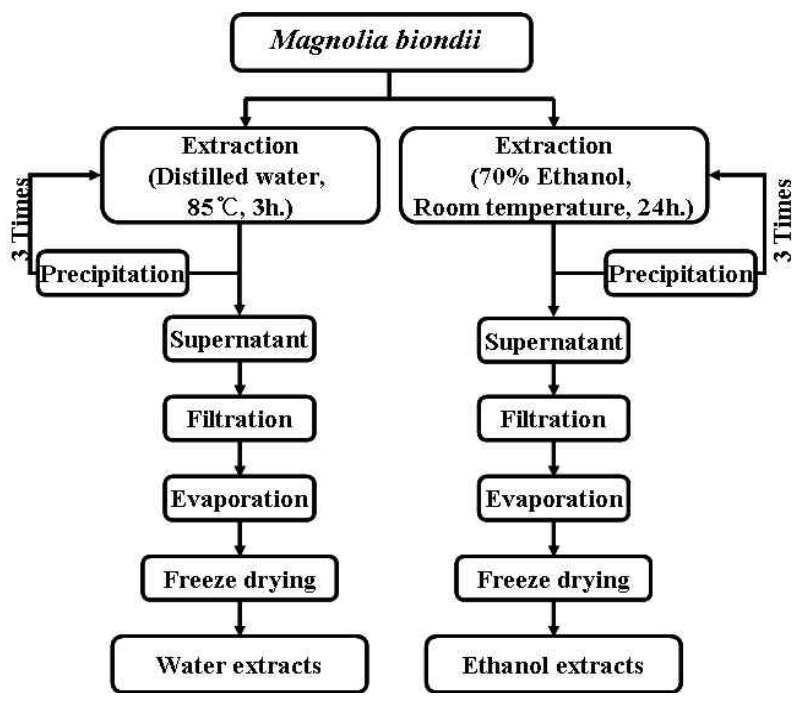

Fig. 1. Procedure for extraction of Magnolia biondii. Water extracts: Magnolia biondii extracted with water, Ethanol extracts: Magnolia biondii extracted with 70\% Ethanol.

+ $10 \mathrm{mM}$ EDTA $2 \mathrm{Na}, \mathrm{pH} 8.5) 260$ lㅏㅇㅘ $7.2 \mathrm{mM}$ pyrogallol $20 \mu 1$ 를 가하여 $25^{\circ} \mathrm{C}$ 에서 10 분간 반응시킨 후 $5 \mathrm{~N} \mathrm{HCl} 10 \mu 1$ 를 가하여 반응을 정지시키고 반응액 중 산화된 pyrogallol의 양 을 UV/VIS spectrophotometer (UV-1800, Shimadzu, Japan) 를 이용하여 $420 \mathrm{~nm}$ 에서 측정하였다.

\section{Xanthine oxidase 저해활성 측정}

신이화추출물의 Xanthine oxidase 저해활성 측정은 Stripe [26] 의 방법을 변형하여 측정하였다. 시료용액 $0.1 \mathrm{ml}$ 와 0.1 $\mathrm{M}$ potassium phosphate buffer ( $\mathrm{pH}$ 7.5) $0.6 \mathrm{ml}$ 에 Xanthine $2 \mathrm{mM}$ 을 녹인 기질액 $0.2 \mathrm{ml}$ 를 첨가하고 Xanthine oxidase $(0.2 \mathrm{U} / \mathrm{ml}) 0.1 \mathrm{ml}$ 를 가하여 $37^{\circ} \mathrm{C}$ 에서 15 분간 반응시킨 후 $1 \mathrm{~N} \mathrm{HCL} 1 \mathrm{ml}$ 를 가하여 반응을 종료시킨 다음 반응액 중에 생성된 Uric acid의 양을 $292 \mathrm{~nm}$ 에서 흡광도를 측정하였다. Xanthine oxidase 저해활성은 신이화추출물 첨가군과 무첨가 군의 흡광도 감소율로 나타낸다.

\section{항염증 측정}

\section{세포 배양 및 세포 생존율 측정}

세포주(RAW $264.7 \mathrm{cells}$ )는 한국세포주 은행에서 분양 받아 $10 \%$ Fetal bovine serum (FBS)과 1\% Penicillin/streptomycin $(100 \mathrm{U} / \mathrm{ml})$ 을 첨가한 Dulbeco's modified eagle's medium (DMEM) 배지를 사용하였으며, $37^{\circ} \mathrm{C}, 5 \% \mathrm{CO}_{2}$ incubator에 적 응시켜 계대 배양하였다. Mouse macrophase RAW 264.7 cells 의 생존율 측정은 Carmichael 등[8]의 MTT assay를 통하여 측정하였다. 96 well plate에 $5 \times 10^{4}$ cells/well로 분주한 후, $80 \%$ 의 Confluency에 도달 할 때 원배지를 제거하고 serum free EMEM으로 교체하였다. 12시간 배양 후, 시료를 농도 별 
로 첨가하여 $37^{\circ} \mathrm{C}, 5 \% \mathrm{CO}_{2}$ Incubator에서 배양하였다. 대조군 은 시료와 동량의 증류수를 첨가하여 동일한 조건으로 배양하 였다. 여기에 $5 \mathrm{mg} / \mathrm{ml}$ 농도로 제조한 MTT 용액 $0.02 \mathrm{ml}$ 를 첨가하여 4 시간 후, 상층액을 제거하고 각 well당 DMSO : $\mathrm{EtOH}(1: 1)$ 를 가하여 실온에서 30 분간 반응 시킨 뒤 ELISA reader로 $550 \mathrm{~nm}$ 에서 흡광도를 측정하였다.

\section{Nitric oxide 저해활성 측정}

Mouse macrophage RAW 264.7 cell로부터 생성된 Nitric oxide의 양은 Kim [16]의 방법을 통하여 다음과 같이 측정하 였다. 세포 배양액 중에 존재하는 $\mathrm{NO}^{2}$ 를 Griess 시약을 이용 하여 측정하였다. 세포배양 상등액 $100 \mu \mathrm{l}$ 와 Griess 시약 100 $\mu 1$ 을 혼합하여 반응하고 10 분 동안 반응시킨 후 $540 \mathrm{~nm}$ 에서 흡광도를 측정하였다.

\section{Western blot analysis에 의한 iNOS 발현량 측정}

iNOS의 발현 측정은 Towbin [28]의 Western blotting을 이 용하여 다음과 같이 측정하였다. Mouse macrophage RAW 264.7 cells에 Lipopolysaccharide (LPS)와 각 농도의 시료를 처리한 후 Cell를 Lysys 하여 $15,000 \times g$ 으로 15 분간 원심분리 하여 Protein을 얻어 Bradford 방법[7]으로 정량 하였다. 얻어 진 Protein은 SDS-polyacrylamide gel을 이용하여 전기영동 시킨 후, N.C membrane으로 Transblotting 하였다. iNOS polyclonal antibody를 이용하여 Membrane에 처리한 후 2차 항 체를 가하여 ECL detecting을 이용하여 iNOS의 발현을 확인 하였다.

\section{결과 및 고찰}

\section{화장품약리활성 측정 결과}

\section{$\mathrm{DPPH}$ radical 소거능 측정}

DPPH radical을 이용한 항산화능 측정법은 주로 Phenolic 구조와 Aromatic amine 화합물에서 많이 사용되는 방법이다. 생체막 구성성분을 파괴하며 각종 산화작용을 나타내는 활성 산소를 소거하여 줄 수 있는 활성을 알아보기 위하여 측정에 사용된 1,1-diphenyl-2-picrylhydrazyl (DPPH)은 안정한 자유 라디칼로서 시료가 항산화 활성을 갖고 있다면, $\mathrm{DPPH}$ 가 갖고 있는 지질산화에 관여하는 Free radical의 비공유결합을 소거 하여 $\mathrm{DPPH}$ 의 환원성을 높이는 것으로, 보라색의 $\mathrm{DPPH}$ 가 환 원이 많이 될수록 보라색을 잃게 되어 UV 측정시 그 수치도 낮아진다. $\mathrm{DPPH}$ 를 첨가하여 반응시켜 추출물이 $\mathrm{DPPH}$ 의 비 공유전자를 소거했을 때 그것의 비공유전자로 인해 $517 \mathrm{~nm}$ 부근에서 최대 흡수치를 나타낸다. 전자 또는 수소를 받으면 $517 \mathrm{~nm}$ 부근에서 흡광도가 감소한다. Rice-Evans [24]은 전자 공여능이 Phenolic acid와 Flavonoids 및 기타 phenol성 물질 에 대한 항산화작용의 지표라 하였으며, 이러한 물질은 환원 력이 클 것일수록 전자공여능이 높다고 하였다. 각 추출물에
서 이러한 라디칼을 환원시키거나 상쇄시키는 능력이 크면 높은 항산화 활성 및 활성 산소를 비롯한 다른 라디칼에 대한 소거 활성을 기대할 수 있으며, 인체 내에서 활성 라디칼에 의한 노화를 억제하는 척도로도 이용할 수 있다.

이화 추출물의 $\mathrm{DPPH}$ 라디칼 소거능을 측정한 결과 Fig. 2 와 같이 나타내었는데, 열수와 에탄올 추출물 농도가 증가할 수록 DPPH 라디칼 소거능이 증가함을 확인할 수 있었고, 동 일한 농도에서 에탄올 추출물보다는 열수추출물의 DPPH 라 디칼 소거능이 높은 것을 확인할 수 있었다. 또한 EC50을 측정 한 결과 열수와 에탄올의 경우 $45 \mu \mathrm{g} / \mathrm{ml}$ 와 $210 \mu \mathrm{g} / \mathrm{ml}$ 로 나타 내었다. 이 결과 합성항산화제를 대체할 수 있을 것으로 사료 된다. 이는 와송 열수추출물의 $1,000 \mathrm{\mu g} / \mathrm{ml}$ 의 농도에서 $60.6 \%$ 의 DPPH 라디칼 소거능을 나타낸 결과와 비교하여 신이화추 출물의 열수추출물이 우수함을 확인할 수 있었다[11,18].

\section{SOD 유사활성 측정}

활성산소를 제거시키는 대표적인 효소인 Superoxide dismutase는 체내에 필요 이상의 활성산소가 생겼을 때 이것을 중화하는 작용을 하는 물질로 세포에 유해한 환원 산소종을 과산화수소로 전환 시키는 반응 $\left(2 \mathrm{O}_{2}^{-}+2 \mathrm{H}^{+} \rightarrow \mathrm{H}_{2} \mathrm{O}_{2}+\mathrm{O}_{2}\right)$ 의 촉매 효소이며, $\mathrm{SOD}$ 에 의해 생성된 $\mathrm{H}_{2} \mathrm{O}_{2}$ 는 Peroxidase나 Catalase 에 의하여 무해한 물분자와 산소분자로 전환시켜 산소 상해로 부터 생체를 보호하는 기능으로 알려져 있다[12,22]. 또한 $\mathrm{SOD}$ 는 자유 라디칼을 근본적으로 제거하는 효소이고 다른 종류의 항산화제보다 우수한 효과를 나타내기 때문에 의약제 재로서 많은 관심을 일으키고 있으며, 현재 항염증 제제나 피 부 노화방지를 위한 미용제재로 화장품 등에 이용이 되고 있 다[5]. 또한 체내에서 SOD와 역할이 유사한 SOD 유사활성 물질에 대한 연구가 진행되고 있으며, 이것은 산화방지는 물 론 노화 억제와도 밀접한 관계가 있는 것으로 알려져 있다. Fig. 3은 신이화 열수 및 에탄올 추출물의 SOD 유사활성을 측정한 결과인데, $5,000 \mu \mathrm{gg} / \mathrm{ml}$ 에서 열수추출물의 경우 $85 \%$ 유사활성을 나타내었고, 에탄올 추출물의 경우 $43 \%$ 의 유사활 성을 나타내었다. 또한 $\mathrm{EC}_{50}$ 을 측정한 결과, 열수추출물의 경

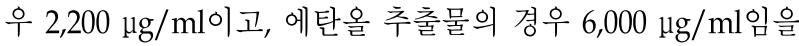
확인할 수 있었고, 열수 및 에탄올 추출물의 농도가 증가할수 록 $\mathrm{SOD}$ 유사활성이 증가함을 볼 수 있고, 에탄올 추출물보다 는 열수추출물에서 더 효과적인 것을 확인할 수 있었다.

\section{Xanthine oxidase 저해능 측정}

Xanthine oxidase는 Purine 대사에 관여하는 효소로서 Xanthine 또는 Hypoxanthine으로부터 Uric acid를 형성하며 Uric acid가 혈장 내에 증가되면 골절에 축적되므로 통증을 동반하는 통풍을 일으키는 효소로 알려져 왔다. Xanthine oxidase는 분자상의 산소를 수소(전자)수용체로 이용하여 Xanthine을 Uric acid형으로 산화하는 반응을 촉진하므로 Xanthine oxidase의 저해효과는 유리 라디칼의 생성 억제와 


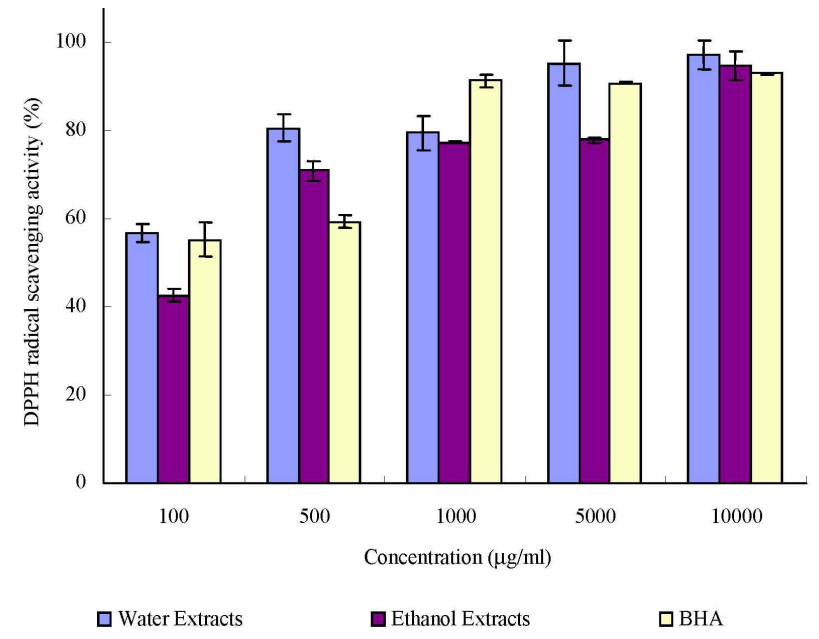

Fig. 2. DPPH radical scavenging activity of the Magnolia biondii extracts. BHA: butylated hydroxyanisole. Results are expressed as means \pm S.D. of triplicate data $(p<0.05)$.

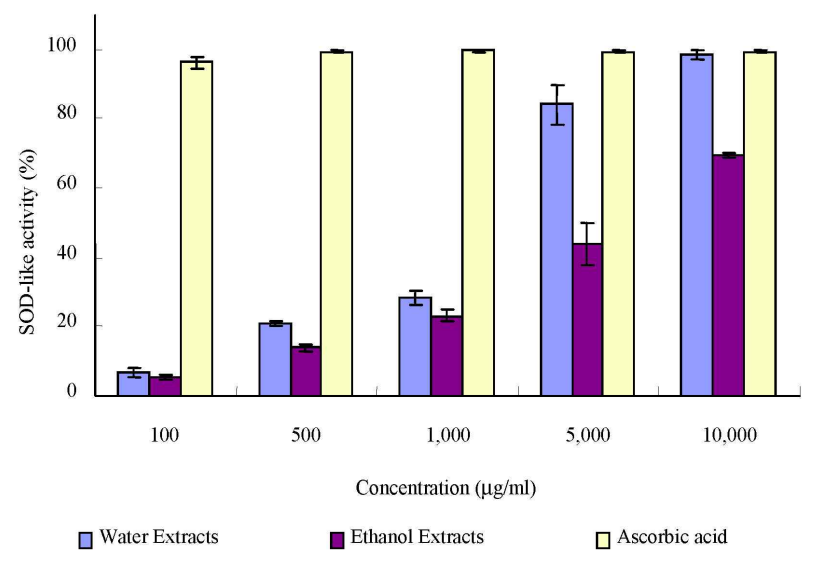

Fig. 3. Superoxide dismutase (SOD)-like activity of the Magndia biondii extracts. Results are expressed as means \pm S.D. of triplicate data $(p<0.05)$.

더불어 생물학적으로 중요한 의의를 가진다고 할 수 있다. Xanthine oxidase 저해활성 방법으로Chiang 등[10]은 양치 식물류인 Alsophila spinulosa (자사라) 추출물로 항산화 효과 를 확인 하였으며, Hatano [14]은 감초추출물로 항산화 효 과를 확인하였다. Fig. 4 는 신이화 추출물의 Xanthin oxidase 저해활성을 측정한 결과인데, 열수추출물의 경우 500 $\mu \mathrm{g} / \mathrm{ml}$ 농도에서 $55 \%$ 이상의 우수한 항산화 효과를 보였으 며, 대조군인 $\mathrm{BHA}$ 보다 우수한 것을 확인할 수 있다. $\mathrm{EC}_{50}$ 을 측정한 결과, 열수추출물의 경우 $410 \mu \mathrm{g} / \mathrm{ml}$ 이었고, 에탄올 추출물의 경우 $750 \mathrm{\mu g} / \mathrm{ml}$ 을 나타내었다. 또한, 신이화 열수 와 에탄올 추출물 $5,000 \mu \mathrm{g} / \mathrm{ml}$ 이상의 농도에서 모두 대조 군인 $\mathrm{BHA}$ 보다 저해효과가 높아 강력한 Xanthine oxidase 효과를 보여준다.

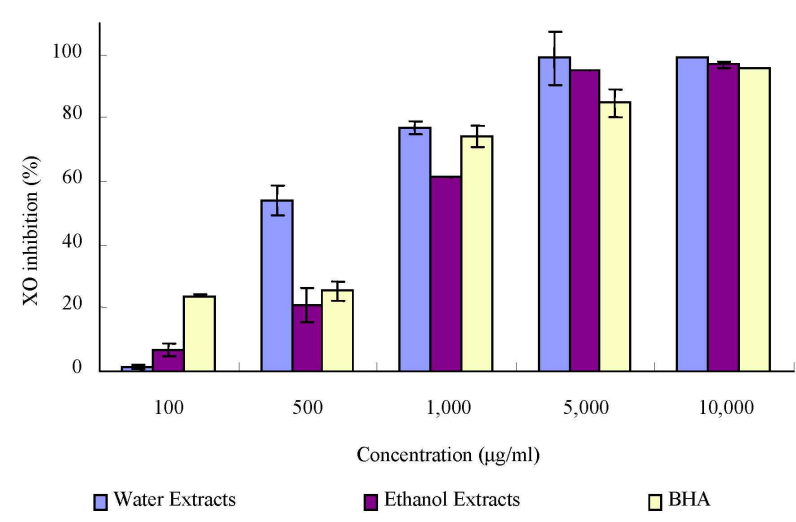

Fig. 4. Xanthine oxidase $(\mathrm{XO})$ inhibition of the Magnolia biondii extracts. BHA: butylated hydroxyanisole. Results are expressed as means \pm S.D. of triplicate data $(\not<0.05)$.

\section{항염증 측정결과}

Nitric oxide 저해능 측정

체내 염증과정에서는 과량의 Nitric oxide (NO) 및 Prostaglandin E2 (PGE2) 등의 염증인자가 유도형 NO synthase (iNOS) 및 Cyclooxygenase (COX)-2에 의해 형성된다. 이중 $\mathrm{NO}$ 는 체내 방어기능, 신호전달기능, 신경독성, 혈관 확 장 등의 다양한 생리기능을 가지고 있다[20]. Macrophage cell 은 능동 및 수동 면역반응에서 매우 중요한 역할을 한다. Lipopolysaccharide (LPS)에 의한 Macrophage cell의 활성은 다양한 염증 매개 물질(IL-1, IL-6, TNF-) 등을 유도하며, 이러 한 염증매개 물질의 형성은 Phospholipase a2의 활성으로 인 해 Arachidonic acid 가 Prostaglandin으로 바뀌는 과정 및 $\mathrm{NO}$ 형성과정으로 이어지게 된다[11]. 천마[1], 장뇌[17]가 $\mathrm{NO}$ 를 저해한다는 보고가 있으며, 최근 다양한 한국 전통 한약재 에 대한 염증 억제 연구가 진행되고 있다.

추출물 함량에 따른 세포생존율을 측정한 결과 모든 농도에 서 세포독성이 없는 것을 확인할 수 있었다. Fig. 5는 LPS를 처리한 Macrophage cell에서는 신이화추출물의 NO의 억제 측정 결과를 나타내었다. LPS처리한 세포에서 $\mathrm{NO}$ 발현량이 현저히 증가함을 보였는데, 열수추출물 $(\mathrm{A})$ 과 에탄올추출물 $(\mathrm{B})$ 에서 함량이 증가 할수록 $\mathrm{NO}$ 발현량이 감소하여 항염증 효과 를 보여준다. $\mathrm{NO}$ 저해 효과를 나타내어 항염증 소재로서의 사용이 가능할 것으로 사료된다.

\section{iNOS 발현량 측정}

Nitric oxide 생성 저해 기작에 대한 iNOS 단백질의 관련성 을 조사하기 위해 Western blot을 이용하여 세포내의 iNOS 단백질의 발현량을 측정한 결과 Fig. 6과 같이 나타내었다. LPS 단독 처리시에는 iNOS 단백질의 발현량이 강하게 유도 되었으나, 신이화 추출물의 함량이 증가 할수록 iNOS발현량 이 감소함을 확인할 수 있었고, 이를 통해 신이화 추출물이 


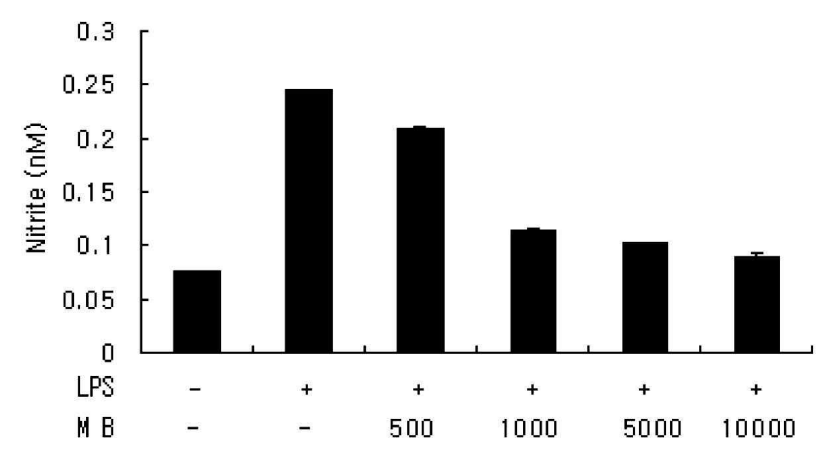

(A)

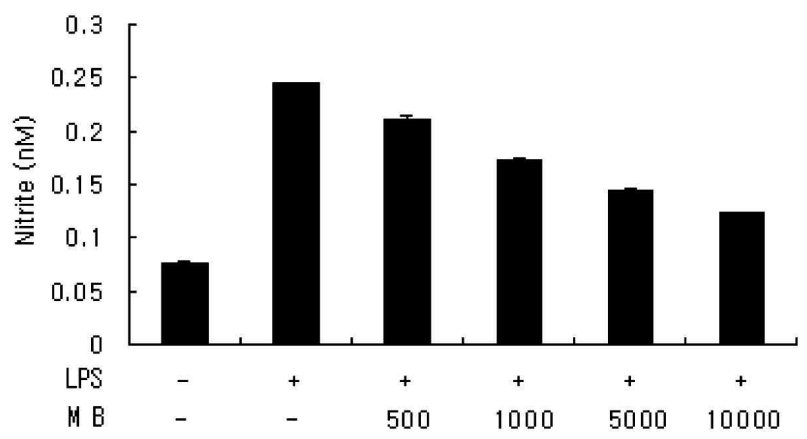

(B)

Fig. 5. Effect of the Magnolia biondii extracts on nitric oxide production of the LPS-stimulated Raw 264.7 macrophage cells. Results are expressed as means \pm S.D. of triplicate data. (A) Water extracts, (B) Ethanol extracts.

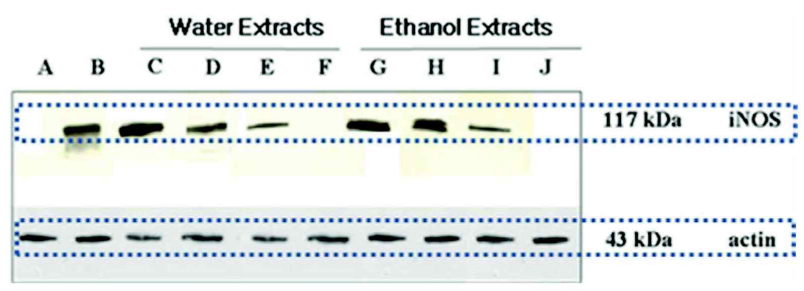

Fig. 6. Effect of the Magnolia biondii extracts on the iNOS expression of the LPS-stimulated Raw 264.7 macrophage cells. A: Control. B: LPS. C: LPS + water extracts 500 $\mu \mathrm{g} / \mathrm{ml}$. D: LPS + water extracts $1,000 \mu \mathrm{g} / \mathrm{ml}$. E: LPS + water extracts $5,000 \mu \mathrm{g} / \mathrm{ml}$. F: LPS + water extracts $10,000 \mu \mathrm{g} / \mathrm{ml}$. G: LPS + ethanol extracts $500 \mu \mathrm{g} / \mathrm{ml}$. $\mathrm{H}$ : LPS + ethanol extracts $1,000 \mu \mathrm{g} / \mathrm{ml}$. I: LPS + ethanol extracts $5,000 \mu \mathrm{g} / \mathrm{ml}$. J: LPS + ethanol extracts $10,000 \mu \mathrm{g} / \mathrm{ml}$.

세포독성 없이 $\mathrm{NO}$ 생성을 억제하고 또한 염증과 관련된 $\mathrm{NO}$ 를 생성하는 iNOS 단백질의 발현량이 줄어든 것을 확인 할 수 있었다.

\section{감사의 글}

본 연구는 중소기업청 2009년 기업부설연구소 설치사업과
지식경제부 2011년 광역경제권 연계협력사업에 의해 수행되 었으며 이에 감사 드립니다.

\section{References}

1. Ahn, E. K., Jeon, H. J., Lim, E. J., Jung, H. J. and Park, E. H. 2007. Anti-inflammatory and anti-angiogenic activities of Gastrodia elata Blume. J. Ethnopharmacol. 110, 476-482.

2. Ames, B. N. 1989. Endogenous oxidative DNA damage, aging and cancer. Free Radic. Res. Commu. 7, 121-128.

3. Aust, S. D., Chignell, C. F., Bray, T. M., Kalyanaraman, B. and Mason, R. P. 1993. Free radicals in toxicology. Toxicol. Appl. Pharm 120, 168-178.

4. Blois, M. S. 1958. Antioxidant determination with the use of a stable free radical. Nature 181, 1199-1200.

5. Bryan, D. M., Murnahan, M. J., Jones, K. S. and Bowley, S. R. 2000. Iron-superoxide dismutase expression in transgenic alfalfa increase winter survival without a detectable increase in photosynthetic oxidative stress tolerance. Plant Physiol. 122, 1427-1438.

6. Branen, A. L. 1975. Toxicology and biochemistry of butylated hydroxyl anisole and butylated hydroxytoluene. J. Am Oil Chem Soc. 52, 59-63.

7. Bradford, M. M. 1976. A rapid and sensitive method for the quantitation of microgram quantities of protein utilizing the principle of protein dye binding. Anal. Biochem 72, 248-254.

8. Carmichael, J., Degraff, W. G., Gazdar, A. F., Minnaand, J. D. and Mitchell, J. B. 1987. Evaluation of a tetrazolium-based semiautomated colorimetric assay: Assessment of chemosensitivity testing. Cancer Res. 47, 936-942.

9. Cha, B. C. and Lee, E. H. 2004. Antioxidant and anti-inflammation activities of Prunus persica tree extracts. Korean J. Medicinal Crop. Sci. 12, 289-294.

10. Chiang, H. C., Lo, Y. J. and Lu, F. J. 1994. Xanthine oxidase inhibitors from the leaves of Alsophila Spinulosa (Hook) Tryon. J. Enzym Inhib. 8, 61-71.

11. Choi, S. Y., Chung, M. J. and Sung, N. J. 2008. Studies on the antioxidative ability of methanol and extracts from Orostachys japonicas A. Berger according to harvest time. Korea J. Food Nutr. 21, 157-164.

12. Funk, C. D., Funk, L. B., Kennedy, M. E., Pong, A. S. and Fitzgerald, G. A. 1991. Human platelet/erythroleukemia cell prostaglandin $\mathrm{G} / \mathrm{H}$ synthase: cDNA cloning, expression and gene chromosomal assignment. FASEB. J5, 2304-2312.

13. Grasbon, T., Grasbon-Frodl, E. M., Juliusson, B., Epstein, C., Brundin, P., Kampik, A. and Ehinger, B. 1999. CuZn superoxide dismutase transgenic retinal transplans. Graefes. Arch Clin. Exp. Ophthalmol. 237, 336-341.

14. Greenstock, C. L. 1993. Radiation and aging: free radical damage, biological response and possible antioxidant intervention. Med Hypotheses 41, 473-482.

15. Hatano, T., Yasuhara, T., Fukuda, T., Noro, T. and Okuda, T. 1989. Phenolic constituents of licorce. II. Structures of licopyranocoumarin, licoaryl-coumarin 
and glisoflavone, and inhibitory effects of licorice phenolics on xanthine oxidase. Chem Pharm Bull. 37, 3005-3009.

16. Jung, S. J., Lee, J. H., Song, H. N., Seong, N. S., Lee, S. E. and Baek, N. I. 2004. Screening for antioxidant activity of plant medicinal extracts. J. Korean Soc. Appl. Biol. Chem 47, $135-140$

17. Kim, B. J., Kim, J. H., Kim, H. P. and Heo, M. Y. 1997. Biological screening of 100 plant for cosmetic use (II): Anti-oxidative activity and free radical scavenging activity. Int. J. Cosm Sci. 19, 299-307.

18. Kim, H. J., Park, T. S., Jung, M. S. and Son, J. H. 2011. Study on the anti-oxidant and anti-inflammatory activities of Sarcocarp and Calyx of Persimon (Cheongdo Bansi). J. Appl. Biol. Chem 54, 71-78.

19. Lee, H. J., Hyun, E. A., Yoon, W. J., Kim, B. H., Rhee, M. H., Kang, H. K., Cho, J. Y. and Yoo, E. S. 2006. In vitro anti-inflammatory and anti-oxidative effects of Cinnamomum camphora extracts. J. Ethnopharmacol. 103, 208-216.

20. Lim, S. S., Shin, K. H., Bang, H. S., Kim, Y. P., Jung, S. H., Kim, Y. J. and Ohuchi, K. 2002. Effect of the essential oil from the flowers of Magnolia sieboldii on the lipopolysaccharide-induced production of nitric oxide and prostaglandin E2 by rat peritoneal macrophages. Planta. Med 68, 459-462.

21. Marklund, S. and Marklund, G. 1974. Involvement of the superoxide anion radical in the autoxidation of pyrogallol and a convenient assay for superoxide dismutase. Eur. $J$. Biochem 47, 469-474.

22. Moncada, S., Palmer, R. M. and Higgs, E. A. 1991. Nitric oxide: physiology, pathophysiology, and pharmacology. Pharmacol. Rev. 43, 109-142.

23. Pan, Y. M., Liang, Y., Wang, H. S. and Liang, M. 2004. Antioxidant activities of several Chinese medicinal herbs. Food Chemistry 88, 347-350.

24. Pryor, W. A. 1986. Oxy-radicals and related species: their formation, lifetimes, and reactions. Annu. Rev. Physiol. 48, 657-667.

25. Pyo, M. K., Lee, Y. and Choi, H. S. 2002. Anti-platelet effect of the constituents isolated from the barks and fruits of Magnolia obovata. Arch Pharm Res. 25, 325-328.

26. Rice-Evans, C. A., Miller, N. J. and Paganga, G. 1996. Structure antioxidant activity relationships of flavonoids and phenolic acids. Free Radic. Biol. Med 0, 933-956.

27. Shen, Y., E. Pang, C. K., Xue, C. C. L., Zhao, Z. Z., Lin, J. G. and Li. C. G. 2008. Inhibitions of mast cell-derived histamine release by different Flos Magnoliae species in rat peritoneal mast cells. Phytomedicine 15, 808-814.

28. Stirpe, F. and Corte, E. D. 1969. The regulation of rat liver xanthine oxidase. J. Biol. Chem 244, 3855-3863.

29. Stohs, S. J. 1995. The role of free radicals in toxicity and disease. J. Basic Clin. Physiol. Pharmacol. 6, 205-228.

30. Towbin, J., Staehlin, T. and Gordon, J. 1979. Electrophoretic transfer of proteins from polyacylamide gels to nitrocellulose sheets: procedure and some applications, Proc. Natl. Acad Sci. USA 76, 4350-4354.

31. Yang, S. E., Hsieh, M. T. and Hsu, S. L. 2003. Effectors mechanism of magnolol-induced apoptosis in human lung squamous carcinoma CH27 cells. Brit. J. Pharmacol. 138, 193-201.

\section{초록 : 신이화(辛夷花, Magnoliae Flos)추출물의 화장품약리활성 및 항염증효과에 관한 연구}

김영훈 ${ }^{1} \cdot$ 성지연 ${ }^{2} \cdot$ 서교성 ${ }^{3} \cdot$ 신재천 $^{4} \cdot$ 김병소 $^{5} \cdot$ 염정현 $^{6} \cdot$ 이진태 ${ }^{7}$ *

(1주)메디웨이코리아 피부과학연구소, ${ }^{2} \mathrm{BIO}-\mathrm{FD \& C}$ 의학나노소재연구소, ${ }^{3}$ 대구경북지방중소기업청, ${ }^{4}$ 포항테 크노바이오정보지원센터, ${ }^{5}$ 영남이공대학 화장품화공계열, ${ }^{6}$ 경북대학교 바이오섬유소재학과, ${ }^{7}$ 대구한의대 학교 화장품약리학과)

본 연구에서는 신이화에 함유된 물질을 열수와 에탄올을 이용하여 추출한 후 화장품약리활성 및 항염증효과를 확인하고, 화장품 및 바이오산업에 적용하기 위한 천연소재로써의 이용 가능성을 살펴보았다. DPPH 라디칼 소 거능 실험결과 농도의존적으로 소거능 효과를 보이며, 열수추출물의 경우 $5,000 \mathrm{ug} / \mathrm{ml}$ 농도에서 대조군인 BHA 보다 우수한 효능을 보였다. SOD 유사활성에서는 농도가 증가할수록 유사활성이 증가하는 것을 확인할 수 있었 고, $5,000 \mathrm{ug} / \mathrm{ml}$ 에서 열수추출물의 경우 $85 \%$ 유사활성을 나타내었고, 에탄올 추출물의 경우 $43 \%$ 의 유사활성을 나타내었다. Xanthine oxidase 저해능 실험에서도 $5,000 \mathrm{ug} / \mathrm{ml}$ 농도에서 대조군 BHA 보다 높은 저해능을 효여 우수한 항산화효과를 보였으며, 합성항산화제를 대체할 수 있는 천연항산화제로 사용이 가능할 것으로 사료된다. 항염증효과를 확인하기 위하여 NO 저해 활성 및 $\mathrm{NOS}$ 발현량을 측정하였는데, 열수와 에탄올 추출물 모두 농도 가 증가할 수로 NO 저해활성과 iNOS 발현량이 감소하여 우수한 항염증효과를 보였다. 이상의 결과에서 신이화 열수추출물과 에탄올추출물은 우수한 화장품약리활성 및 항염증효과가 있음을 확인할 수 있었고, 안티에이징 및 트러블 피부 개선 화장품 소재로서의 가능성을 확인할 수 있었다. 